Ege Tıp Dergisi / Ege Journal of Medicine 2020; 59 (1): 58-60

\title{
Buerger hastalığında trombolitik tedaviye bağlı bir komplikasyon: hemorajik inme ve daha fazlası
}

\section{A complication through thrombolytic treatment in Buerger's disease: hemorrhagic stroke and more}

\author{
Azize Serce ${ }^{1}$ Ebru Karaca Umay ${ }^{2}$ (D) Alican Karakuyu ${ }^{2}$ (D) Fatma Aytül Çakcl ${ }^{2}$ (D) \\ ${ }^{1}$ Malatya Yeşilyurt Hasan Çalık Devlet Hastanesi, Fiziksel Tıp ve Rehabilitasyon Kliniği, Malatya, \\ Türkiye \\ ${ }^{2}$ Sağlık Bilimleri Üniversitesi, Dışkapı Yıldırım Beyazıt Eğitim ve Araştırma Hastanesi, Fiziksel Tıp ve \\ Rehabilitasyon Kliniği, Ankara, Türkiye
}

Öz

Buerger Hastalığı (BH), genellikle alt ve üst ekstremitelerdeki küçük ve orta boy damarların tutulduğu non-aterosklerotik inflamatuvar bir hastalık olup sıklıkla genç, sigara içen erkeklerde görülür. Tedavisinde sigarayı bırakmak, medikal ve cerrahi yöntemler kullanılmakla birlikte, özellikle alt ekstremitelerde akut oklüzyonu olan hastalarda trombolitik tedavilerde bir seçenek olmaktadır. Burada medikal tedaviye dirençli BH'na bağlı alt ekstremite trombozu gelişen ve intra-arteriyel trombolitik tedavi verilen, takibinde intrakraniyal kanaması olan, ilacın kesilmesi sonrası da greft oklüzyonuna bağlı sağ diz üstü ampütasyonu yapılmak zorunda kalınan bir vaka sunulmaktadır. Alt ekstremite iskemilerinde uygulanan trombolitik tedavi sonrası en ciddi kanama komplikasyonu intrakraniyal kanama olup \%1-2 oranında görülebilir. Bizim olgumuzda intrakraniyal hemoraji gelişimi sonrası, antikoagulan tedavinin kesilmesi, hastanın inmeden etkilenmemiş ekstremitesinin amputasyonu sonucunu doğurmuştur.

Anahtar Sözcükler: Buerger hastalığı, hemorajik inme, trombolitik tedavi.

\begin{abstract}
Buerger's disease is a non-atherosclerotic inflammatory disease that usually involves small and midsized vessels of the lower and upper extremities, and is often seen in young, smoker males. In the treatment of give up smoking, medical and surgical methods are used, especially in patients with acute occlusion of the lower extremities, thrombolytic treatments are an option. Here, we present a case with right knee amputation due to graft occlusion and discontinuation of the drug after the discontinuation of the drug. After thrombolytic therapy in lower extremity ischemia, the most serious bleeding complication is intracranial hemorrhage with a rate of $1-2 \%$. In our case, after the development of intracranial hemorrhage, discontinuation of anticoagulant treatment resulted in amputation of the unaffected extremity of the patient.
\end{abstract}

Keywords: Buerger's disease, hemorrhagic stroke, thrombolytic treatment.

\section{Giriş}

Tromboanjiitis obliterans veya diğer adıyla Buerger Hastalığı (BH), etkilenen damarlarda tromboz ve rekanalizasyon ile karakterize, arter ve venlerin segmental, okluziv, inflamatuar bir durumu olup sıklıkla genç, sigara içen erkeklerde görülür. Genellikle alt ve üst ekstremitelerdeki küçük ve orta boy damarların tutulduğu nonaterosklerotik inflamatuar bir hastalıktır $(1,2)$.

\footnotetext{
Yazışma Adresi: Azize Serce

Malatya Yeşilyurt Hasan Çalık Devlet Hastanesi, Fiziksel Tıp ve Rehabilitasyon Kliniği, Malatya, Türkiye

E-mail: azizedc37@hotmail.com

Makalenin Geliş Tarihi: 27.12.2018 Kabul Tarihi: 31.01.2019
} 
Hastalık tüm dünyada görülmekle birlikte en yüksek görülme oranı Orta ve Uzak Doğu'dadır (1). Coğrafi farklılıklar göstermesi, BH ve obliteratif ateroskleroz arasındaki ayrımın yapılmasında kullanılabilecek non-invaziv tanı metodlarının eksikliği ve kullanılan tanı kriterlerinin farklı olması nedeniyle hastalığın gerçek prevalansı bilinmemektedir $(1,3)$.

Tedavisinde sigarayı bırakmak, medikal ve cerrahi yöntemler kullanılmakla birlikte, özellikle alt ekstremitesinde akut oklüzyonu olan hastalarda kataterle uygulanan doku plasminojen aktivatörü (TPA) gibi trombolitik tedavilerde bir tedavi seçeneği olmaktadır. Son yıllarda uygulama sıklığı artan trombolitik tedavinin başarı şansı yüksek olmakla birlikte, \%1-2 sıklığında major kanamalara yol açabilmektedir (4).

Burada medikal tedaviye dirençli BH'na bağlı alt ekstremite trombozu gelişen ve intra arteriyel trombolitik tedavi verilen, takibinde intrakraniyal kanaması olan, ilacın kesilmesi sonrası da greft oklüzyonuna bağlı sağ diz üstü ampütasyonu yapılan bir vaka sunulmaktadır.

\section{Olgu Sunumu}

50 yaşında erkek hasta, 20 yıl önce sağ ayakta ağrı, renk değişikliği, uyuşukluk, soğukluk egzersizle kladikasyo yakınmaları olması nedeniyle yapılan tetkikleri sonucunda $\mathrm{BH}$ tanısı almış. Hastaya medikal olarak asetilsalisilik asit $1 \times 100 \mathrm{mg} / g u ̈ n$ tedavisi başlanmış. Semptomları gerilemeyen hastaya tanı aldıktan 2 ay sonra sağ femoropopliteal bypass operasyonu yapılmış. Tanıdan 10 yıl sonra, sol bacağında da yakınmaları olunca sol femoropopliteal bypass operasyonu da uygulanmış. Üst ekstremitelerinde yakınması hiç olmamış. Bu süre zarfında tedavisine klopidogrel $1 \times 75 \mathrm{mg} / \mathrm{gün}$, asetil salisilik asit $1 \times 100 \mathrm{mg} / \mathrm{gün}$, pentoksifilin $3 \times 400 \mathrm{mg} / \mathrm{gün}$, silostazol $2 \times 100$ $\mathrm{mg} /$ gün olarak ilaçlar eklenmiş.

Hastanın tanıdan 18 yıl sonra, aldığı tüm tedavilerine rağmen sağ bacakta ağrı ve soğukluk yakınması olması nedeniyle yapılan dijital substraksiyon anjiografisinde (DSA); sağ superior femoral arter (SFA) ve popliteal arterinde trombüs olduğu ve damar lümeninin oklüde olduğu saptanmış ve kataterle doku plasminojen aktivatörü (TPA) tedavisi uygulanmış. Bundan bir yıl sonra sağ bacağındaki ağrı ve soğukluk yakınması tekrar eden hastanın DSA'sında sağ SFA'da total oklüzyon, femoropopliteal greftin de total oklüde olduğu görülmüş ve tromboze greft nedeniyle yeniden $2 \mathrm{mg} / \mathrm{saatten}$ selektif TPA tedavisi başlanmış. Tedavinin 15 . saatinde sol kol ve bacağında güçsüzlük gelişen hastanın bilgisayarlı beyin tomografisinde sağda bazal ganglion düzeyinde $48 \times 16 \mathrm{~mm}$ ventriküler sisteme açılım gözlenen parankimal hematom, ayrıca solda sentrum semiovalede $21 \times 18 \mathrm{~mm}$ parankimal hematom, bilateral temporopariatelde subaraknoid kanama ile uyumlu dansiteler saptanmış. Hastanın trombolitik tedavisi kesilerek 2 ünite taze donmuş plazma verilmiş ve antiödem tedavisi olarak mannitol ve dekort tedavisi başlanmış. Karotis ve vertebral arter doppler ultrasonografilerinde patoloji saptanmamış.

Sağ bacağındaki greftinde oklüzyonu devam eden ve siyanozu gelişen hastaya intrakraniyal kanamadan bir gün sonra diz üstü ampütasyon yapılmış. Takibinde üç ay yoğun bakımda kalma öyküsü olan hasta sonrasında nöroloji servisine alınmış. Yoğun bakımda yatışı sırasında akciğer aspirasyonları olan ve oral alımı bozulan hastaya trakeostomi ve perkutan endoskopik gastrostomi açılmış.

Hasta hemorajik inme sonrası sol hemipleji nedeni ile rehabilitasyon amacıyla olay tarihinden yaklaşık bir yıl sonra kliniğimize kabul edildi. Hastanın muayenesinde genel durumu orta, bilinci açık, koopere ve oryante idi. Sistemik muayenesi solda alt ekstremitesinde distal nabızların alınamaması dışında doğaldı, sağ bacak diz üstünden ampute, perkutan endoskopik gastrostomi ve trakeostomisi mevcuttu. Yatak seviyesinde olan ve destekle oturabilen hastanın solda Brunnstrom motor evrelemesi el: $3 / 6$, üst ekstremite: $3 / 6$, alt ekstremite: $4 / 6$ olarak değerlendirildi. Derin duyu korunmuş, yüzeyel duyu solda bozuk, 2 nokta ayrımı $1 \mathrm{~cm}$, derin tendon refleksleri solda hiperaktifti. Hastada spastisite ve bası yarası saptanmadı.

Tam kan, biyokimya, lipit profili, hepatit B-C, sedimentasyon, $C$ reaktif protein, idrar analizi ve transtorasik ekokardiyogramında patoloji saptanmadı.

Özgeçmişinden şoförlük yaptığı, 33 paket/yıl sigara içme öyküsünün olduğu, alkol ve madde kullanımının olmadığı, altı yıldır esansiyel primer hipertansiyon tanısıyla nifedipin $1 \times 30 \mathrm{mg} / \mathrm{gün}$ ve perindopril $1 \times 10 \mathrm{mg} / g u ̈ n$ kullandığı ve hastada hiç koroner ve mezenterik vasküler tutulum olmadığı öğrenildi.

Hastadan tıbbi verilerinin yayınlanabileceğine ilişkin yazılı onam belgesi alındı.

\section{Tartışma}

$\mathrm{BH}$ genellikle 40-45 yaş arasında kol, bacak, el ve ayaklardaki distal küçük damarların iskemisi ile başlar ve erkeklerde daha sık görülür $(1,2)$. En sık görülen klinik bulgular ekstremitelerde soğukluk, parestezi, deri renginde değişiklikler, 
kladikasyo, iskemik ülserasyonlar ve istirahat ağrısıdır (3).

BH sıklıkla ekstremitelerdeki küçük ve orta büyüklükteki arter ve venleri tutmakla birlikte serebral ve koroner arterler, aorta, intestinal damarlar ve hatta çoklu organ tutulumları görülebilir (1). Serebral tutulum seyrek olmakla birlikte özellikle sigara içmek dışında diğer kardiyovasküler risk faktörlerini de taşıyan hastalarda beyin enfarktüsü nedeni olabilir (2). Serebral $\mathrm{BH}$ tanısı sıklıkla dijital gangren ve serebral iskemik olaylara yol açan diğer hastalıkların dışlanması ile mümkündür. Buerger hastalarında serebral tutulum görülme sıklığı \%0,5-18 arasında değişmektedir (5). Hastalık koroner, serebral, mezenterik tutulum gibi beklenmeyen-olağandışı bir yerde görüldüğünde kesin tanı yalnızca histopatolojik inceleme ile konulabilmektedir (6). İnme $\mathrm{BH}$ ile senkronize olarak yada tanıdan yıllar sonra görülebilir (2).

Bizim hastamızda intrakraniyal hemorajinin intraarteriyel TPA tedavisi sırasında gelişmesi ve vaskülit bulgularının olmaması bu durumun ilaca bağlı geliştiğini bize düşündürdü.

Periferik arter tıkanıklığına ve bypass greft trombozuna bağlı alt ekstremite iskemilerinde uygulanan tromboliz tedavisi sık uygulanan etkin bir tedavi olup birçok hastada büyük cerrahi müdahaleler olmaksızın kesin tedavi sağlayabilir (4). Cerrahi trombektomi ile karşılaştırıldığında trombolitik tedavide cerrahi travma, inflamatuar yanıt, analjezik intiyacı, immobilizasyon, postoperatif enfeksiyon ve ampütasyon daha az görülmektedir (7). Ancak trombolitik tedavi ile distal embolizasyon ve majör kanama riski daha fazladır (8). En ciddi kanama komplikasyonu intrakraniyal kanama olup intra-trombus infüzyonu ve doz kısıtlaması önlemlerine rağmen \%1-2 oranında görülebilir (4).

Kanama komplikasyonu varlığında, ilacın kesilip antifibrinolitik ilaç (aminokaproik asit) verilerek, kanama zamanı ve fibrinojen düzeyleri bakılmalıdır (9).

İskemik inmeli hastalarda TPA uygulanmasını takiben \%2,9-6,4 oranlarında hemorajik transformasyon bildirilmiştir, fakat $\mathrm{BH}$ tedavisi nedeniyle kullanımı sonrasında gelişen hemorajik inme literatürde bildirilmemiştir.

Son yıllarda yapılan metaanaliz ve derlemelerde halen tedavisinde kesin kuralların olmadığı, antikoagulanların yaygın kullanımına rağmen yararı ile ilgili sonuçların tartışmalı olduğu bildirilmektedir (10).

$\mathrm{BH}$ 'de uygulanan intra-arteriyel trombolitik tedaviler sonrasında, \%1-2 oranında intrakraniyal hemoraji gibi majör kanamalar olabilmekte ve hastanın tedavisinin kesilmesi damarlarda oklüzyon ve takibinde ek komplikasyonlara yol açabilmektedir. Bizim olgumuzda da intrakraniyal hemoraji gelişimi sonrası antikoagulan tedavinin kesilmesi, hastanın inmeden etkilenmemiş ekstremitesinin amputasyonu sonucunu doğurmuştur. Bu hastaların tedavi sürecinde dikkatli bir şekilde yakından takip edilmesi oluşabilecek komplikasyonları en aza indirmek açısından büyük önem taşımaktadır.

\section{Kaynaklar}

1. Arkkila PE. Thromboangiitis obliterans (Buerger's disease). Orphanet journal of rare diseases. $2006 ; 1: 14$.

2. Wen-Wei Huang C-HW, Chien-Feng Li, Ming-Chyi Pai. Late Onset Buerger's Disease with Multiple Cerebral Infarcts. Tzu Chi Med J. 2007; 19: 28-31.

3. Malecki R, Kluz J, Przezdziecka-Dolyk J, Adamiec R. The Pathogenesis and Diagnosis of Thromboangiitis obliterans: Is It Still a Mystery? Advances in clinical and experimental medicine : official organ Wroclaw Medical University. 2015; 24 (6): 1085-97.

4. Giannini D, Balbarini A. Thrombolytic therapy in peripheral arterial disease. Current drug targets Cardiovascular \& haematological disorders. 2004; 4 (3): 249-58.

5. Biller J, Asconape J, Challa VR, Toole JF, McLean WT. A case for cerebral thromboangiitis obliterans. Stroke. 1981; 12 (5): 686-9.

6. Olin JW, Young JR, Graor RA, Ruschhaupt WF, Bartholomew JR. The changing clinical spectrum of thromboangiitis obliterans (Buerger's disease). Circulation. 1990; 82 (5 Suppl): IV3-8.

7. Koraen L, Kuoppala M, Acosta S, Wahlgren CM. Thrombolysis for lower extremity bypass graft occlusion. Journal of vascular surgery. 2011; 54 (5): 1339-44.

8. Clagett GP, Sobel M, Jackson MR, Lip GY, Tangelder M, Verhaeghe R. Antithrombotic therapy in peripheral arterial occlusive disease: the Seventh ACCP Conference on Antithrombotic and Thrombolytic Therapy. Chest. 2004; 126 (3 Suppl): 609-26.

9. Cacione DG, Macedo CR, Baptista-Silva JC. Pharmacological treatment for Buerger's disease. The Cochrane database of systematic reviews. 2016; 3: CD011033.

10. Klein-Weigel P, Volz TS, Zange L, Richter J. Buerger's disease: providing integrated care. Journal of multidisciplinary healthcare. 2016; 9: 511-8. 